\title{
ANALISIS SISTEM INFORMASI PELAYANAN JASA IN-HOUSE TRAINING PADA PT SIGMA GLOBAL INTERNASIONAL JAKARTA
}

\author{
Agus Hamdi \\ Information Systems Department, School of Information Systems, Binus University \\ Jl. K.H. Syahdan No. 9, Palmerah, Jakarta Barat 11480 \\ agushamdi@yahoo.co.id
}

\begin{abstract}
One key to success is the company's strategy to improve performance in information systems that are reliable. Effective information is expected to help companies to do things related to the mechanism of decisionmaking quality, efficient management process, as well as effective communication and collaboration culture. PT Sigma Global International Jakarta is a private training and consulting services nationwide that provides consulting services in the aspects of customer satisfaction and do sales through creative and innovative work of all competent employees. To see and resolve the weaknesses that occur in the system in-house training services PT Sigma Global International Jakarta needs evaluation and analysis.
\end{abstract}

Keywords: consulting, system information, services

\begin{abstract}
ABSTRAK
Salah satu kunci keberhasilan strategi peningkatan kinerja perusahaan adalah pada sistem informasi yang andal. Adanya informasi yang efektif diharapkan dapat membantu perusahaan untuk melakukan hal-hal yang terkait dengan mekanisme proses pengambilan keputusan yang berkualitas, proses penyelengaraan manajemen yang efesien, dan budaya komunikasi dan berkolaborasi yang efektif. PT Sigma Global Internasional Jakarta merupakan perusahaan jasa konsultasi dan pelatihan swasta nasional yang melakukan penjualan melalui karya yang kreatif dan inovatif dari seluruh karyawan yang kompeten. Untuk melihat dan menyelesaikan kelemahan-kelemahan yang terjadi pada sistem pelayanan jasa in-house training PT Sigma Global Internasional Jakarta diperlukan evaluasi dan analisis pada sistem informasi yang ada.
\end{abstract}

Kata kunci: konsultasi, sistem informasi, pelayanan jasa 


\section{PENDAHULUAN}

Perusahaan sebagai organisasi yang memiliki kecenderungan orientasi pada laba, selalu membutuhkan sistem yang terkomputerisasi dalam mengumpulkan, menyimpan, dan memproses data untuk menghasilkan informasi yang dapat membantu perusahaan dalam melakukan perencanaan strategi dan pengambilan suatu keputusan secara efektif. Tanpa adanya sistem yang berbasis komputer, perusahaan akan menghadapi kendala untuk mendapatkan informasi yang aktual dan akurat. Informasi dapat diperoleh dari sistem informasi (informations systems) atau disebut juga dengan processing systems atau information-generating systems. Sistem Informasi adalah suatu sistem didalam suatu organisasi yang mempertemukan kebutuhan pengolahan transaksiharian yang mendukung fungsi operasi organisasi yang bersifat manajerial dengan kegiatan strategi dari suatu organisasi untuk dapat menyediakan kepada pihak luar tertentu dengan laporan-laporan yang diperlukan (Sutabri, 2005).

PT Sigma Global Internasional Jakarta merupakan perusahaan yang bergerak dalam bidang jasa dan pelatihan. Salah satu produknya adalah in-house training. Menurut Kemaludin (2011), inhouse training adalah program pelatihan atau training yang diselenggarakan oleh suatu perusahaan atau organisasi dengan menggunakan tempat pelatihan sendiri, peralatan sendiri, menentukan peserta dan dengan mendatangkan Trainer sendiri. Pada saat ini sistem informasi pada pelayanan jasa inhouse training di PT Sigma Global Internasional Jakarta belum menggunakan peralatan teknologi informasi sehingga kinerjanya belum efektif karena masih dilakukan secara manual. Hal itu tercermin pada seringnya terjadi keterlambatan penyusunan laporan dan kesalahan pencatatan serta pengulangan dalam pencatatan transaksi. Oleh karena itu, diperlukan suatu sistem informasi yang mampu mengatasi masalah yang dihadapi. Tujuan dilakukan penelitian ini adalah untuk mengevaluasi sistem informasi pelayanan jasa in-house training di PT Sigma Global Internasional Jakarta yang ada sekarang ini dan menganalisis kelemahan-kelemahan yang ada pada sistem yang sedang berjalan tersebut.

\section{METODE}

Dalam pengumpulan data dan informasi bagi keperluan penelitian untuk mendapatkan data yang diperlukan yaitu dengan metode sebagai berikut: (1) observasi, yaitu penulis melakukan penelitian langsung ke bagian supervisor manager untuk memperoleh informasi serta mengumpulkan data dari pimpinan, dan para karyawan; (2) wawancara langsung dengan pimpinan, staf perusahaan dalam rangka pengumpulan data serta informasi tentang kegiatan pelayanan jasa in-house training yang dijalankan; (3) studi kepustakaan, dengan membaca dan mencari informasi dari buku-buku, makalah dan sumber data lainnya sebagai referensi yang berhubungan penelitian.

\section{HASIL DAN PEMBAHASAN}

Setelah melakukan penelitian dan mengindentifikasi masalah yang dihadapi terhadap sistem informasi pelayanan jasa in-house training di PT Sigma Global Internasional Jakarta, hasil yang dapat disampaikan adalah: (1) sistem informasi pelayanan jasa in-house training di PT Sigma Global Internasional Jakarta, dalam proses pengolahan datanya tidak menggunakan sistem berbasis komputer yang menyebabkan terjadi keterlambatan penyampaian informasi untuk penyusunan laporan, kesalahan dalam pencatatan dan pengulangan dalam pencatatan transaksi; (2) perusahaan ini menggunakan banyak dokumen dalam bentuk kertas yang dapat menghambat proses pelaporan yang harus di serahkan banyak memakan waktu ; (3) dalam proses penyimpanan data kurang terjamin 
keamanannya, karena banyak data atau arsip yang digunakan sedangkan ruang untuk penyimpanan terbatas, dan apabila dalam proses pencarian data atau arsip memerlukan waktu yang cukup lama.

Untuk permasalahan yang terjadi pada sistem pelayanan jasa in-house training di atas, alternatif pemecahannya yaitu diperlukan suatu sistem informasi berbasis komputer sehingga dalam proses pengolahan data, pembuatan laporan dan pencarian informasi yang diperlukan menjadi lebih cepat, efisien dan tepat waktu, selain itu juga mempunyai beberapa keuntungan di antaranya sebagai berikut: (1) pekerjaan yang dilakukan dapat lebih akurat, tepat waktu, efisien dan efektif; (2) memudahkan bagian Marketing Staff dan Financial Staff dalam pembuatan laporan, sehingga pekerjaan dapat selesai tepat pada waktunya dan hasilnya akan lebih memuaskan; (3) data akan tersimpan dengan baik di dalam database, sehingga keamanan data lebih terjamin dan pencarian data pun akan lebih cepat.

\section{Sistem berjalan pada Pelayanan Jasa In-House Training}

Adapun prosedur sistem berjalan pelayanan jasa in-house training pada PT Sigma Global Internasional Jakarta dari tahap awal hingga akhir sebagai berikut:

\section{Permintaan In-House Training}

Prosedur permintaan in-house training dimulai dari Client melihat website PT Sigma Global Internasional Jakarta. Di dalam website berisi tema-tema dari in-house training, Trainer in-house training, harga in-house training. Jika tertarik dengan salah satu tema in-house training, Client melakukan permintaan pemesanan melalui telepon ke Marketing Staff. Marketing Staff menggali kebutuhan training yang diperlukan. Setelah itu, Marketing Staff akan melihat Arsip Training untuk membuat Form In-house Kosong (FIHK) dan mengirimkannya ke Client melalui fax atau email. Form In-house Kosong (FIHK) tersebut di isi dengan pokok permasalahan yang ingin dibahas dalam training. Setelah terisi dengan lengkap Form In-house (FIH) dikembalikan ke Marketing jStaff. Setelah itu, Marketing Staff mengarsipkan Form In-house (FIH) menjadi arsip FIH.

\section{Persetujuan}

Berdasarkan arsip FIH, Marketing Staff akan memberikan Form In-house (FIH) kepada Trainer untuk memberitahukan pokok-pokok pembahasan yang akan dipresentasikan. Marketing Staff melakukan follow up kembali untuk kepastian presentasi. Jika Client menyetujui presentasi tersebut, maka Marketing Staff menghubungi Trainer yang memiliki background dari tema yang akan dibahas dalam training. Selanjutnya, Trainer membuat Silabus yang akan diberikan kepada Marketing Staff. Silabus tersebut kemudian diarsipkan menjadi arsip Silabus oleh Marketing Staff.

\section{Negosiasi}

Trainer membuat Silabus tentang materi in-house training. Kemudian berdasarkan arsip Silabus tersebut, dibuat Surat Penawaran (SP) dan Proposal Training (PT) oleh Marketing Staff . Kemudian Marketing Staff membuat Surat Penawaran (SP) lalu diarsipkan menjadi Arsip SP. Berdasarkan Arsip SP, maka Marketing Staff mengirimkan Surat Penawaran (SP) sebagai surat penawaran training yang berisi outline training sebagai ruang lingkup kajian yang akan dibahas di dalam seminar serta Marketing Staff juga mengirimkan Proposal Training (PT) ke Client. Setelah membaca isi Proposal Training (PT), dilanjutkan dengan negosiasi harga dan tanggal pelaksanaan inhouse training. Jika pihak Client menyetujui Proposal Training (PT) tersebut, Client menandatangani Proposal Training (PT) dan mengirim kembali Fotocopy Proposal Acc (CP_Acc) kepada Marketing Staff. Kemudian Marketing Staff mengarsipkan Fotocopy Proposal Acc in-house training menjadi arsip CP_Acc. 


\section{Pembayaran}

Setelah pihak Client menandatangani Proposal Training (PT) dan mengirim kembali ke Marketing Staff, maka pihak Client akan menerbitkan Purchase Order (PO) untuk perusahaan training dan memberikan Bukti Transfer (BT) yang akan diajukan kepada Marketing Staff. Setelah itu, Marketing Staff memberikan Purchase Order (PO) dan Bukti Transfer (BT) ke bagian Financial Staff untuk dibuatkan Invoice dan Kwitansi bermaterai.

Financial Staff membuat Invoice, Kwitansi dan Faktur Pajak yang akan diberikan kepada Marketing Staff sebagai bukti pembayaran,dan pemotongan pajak. Setalah itu, Financial Staff juga mengembalikan Purchase Order (PO).

Invoice, Kwitansi dan Faktur Pajak sebagai bukti pembayaran dan pemotongan pajak akan diberikan ke Client. Kemudian Purchase Order (PO) diarsipkan menjadi arsip PO, Invoice menjadi arsip Invoice, Kwitansi diarsipkan menjadi arsip Kwitansi dan Faktur Pajak diarsip menjadi arsip Faktur. Setelah itu, Marketing Staff membuat data bayar berdasarkan menjadi arsip PO, arsip Invoice, arsip Kwitansi, arsip Faktur sebagai bukti pembayaran masuk training.

\section{Pelaksanaan In-House Training}

Pada hari pelaksanaan, pihak Client telah menyediakan fasilitas untuk training seperti tempat, akomodasi, konsumsi baik untuk peserta atau Marketing Staff dalam training tersebut. Marketing Staff memberikan Daftar Hadir Kosong (DHK) untuk mengetahui kehadiran Peserta dari perusahaan Client dan Form Biodata Kosong (FBK) untuk mengisi biodata para peserta training. Setelah terisi dengan lengkap Daftar Hadir (DH) dan Form Biodata (FB) dikembalikan ke Marketing Staff. Marketing Staff juga memberikan Form Evaluasi In-house Training Kosong (FEK) ke Peserta. Setelah terisi dengan lengkap Form Evaluasi In-house Training (FE) dikembalikan ke Marketing Staff. Kemudian Marketing Staff memberikan sertifikat, softcopy materi dan souvenir sebagai bukti peserta telah mengikuti training. Marketing Staff juga memberikan 2 (dua) rangkap Berita Acara Serah Terima (BAST) yaitu BAST_rangkap1 dan BAST_rangkap2 ke Client yang digunakan sebagai bukti penyelenggarakan training yang telah dilakukan untuk disetujui. Kemudian BAST_rangkap2 yang telah disetujui (BAST_rangkap2_Acc) dikembalikan ke Marketing Staff, sedangkan BAST_rangkap1_Acc disimpan oleh Client. Kemudian Daftar Hadir (DH) diarsip menjadi arsip DH, Form Biodata (FB) menjadi arsip FB, Form Evaluasi In-house Training (FE) menjadi arsip FE dan BAST_rangkap2_Acc diarsipkan menjadi arsip BAST_rangkap2_Acc. Setelah itu, Marketing Staff membuat Bukti Pengeluaran Kas (BPK) sebagai bukti pengeluaran biaya training, lalu si arsipkan menjadi arsip BPK.

\section{Pembuatan Laporan In-House Training}

Pembuatan laporan in-house training didasarkan pada arsip LK yang telah dibuat oleh Marketing Staff pada saat pelaksanaan training yaitu berdasarkan Arsip BAST_rangkap2_Acc. Karena in-house training ini belum tentu terjadi setiap bulannya, setiap terjadi training akan dicatat dan dibuat menjadi Laporan Training Pertahun (LTP) yaitu berdasarkan arsip bayar dan arsi BPK. Data flow diagram digambarkan sebagai berikut (Gambar 1 -4).

\section{PENUTUP}

Berdasarkan evaluasi dan analisis terhadap Sistem informasi pelayanan jasa in-house training pada PT Sigma Global Internasional Jakarta yang dilakukan secara manual, dapat 
disimpulkan bahwa proses pelayananjasa kurang efisien dan memakan waktu lama dalam pembuatan laporan. Untuk mengatasi kekurangan yang ada pada sistem manual perlu dirancang sistem berjalan yang dibuat secara komputerisasi yang memberikan banyak kemudahan di antaranya: (1) informasi tentang pelayanan jasa in-house training dapat dengan mudah diperoleh (2) penyimpanan data yang berhubungan dengan pelayanan jasa in-house training dapat dilakukan dengan cepat, tepat dan efisien; (3) laporan yang sewaktu-waktu dibutuhkan dapat diselesaikan dalam waktu singkat; (4) meminimalisasi kesalahan-kesalahan yang akan mungkin terjadi pada sistem manual; (5) menyimpan data akan lebih efektif dan efisien.

\section{DAFTAR PUSTAKA}

Kemaludin, Lulu. (2011). Definisi In-house Training. Diakses 20 Mei 2012 dari: http://tikettraining.com/pengertian-in-house-training-tujuan-dan-manfaatnya.html.

Sutabri, Tata. (2005). Sistem Informasi Manajemen. Yogyakarta: Andi Offset. 


\section{APPENDIX}

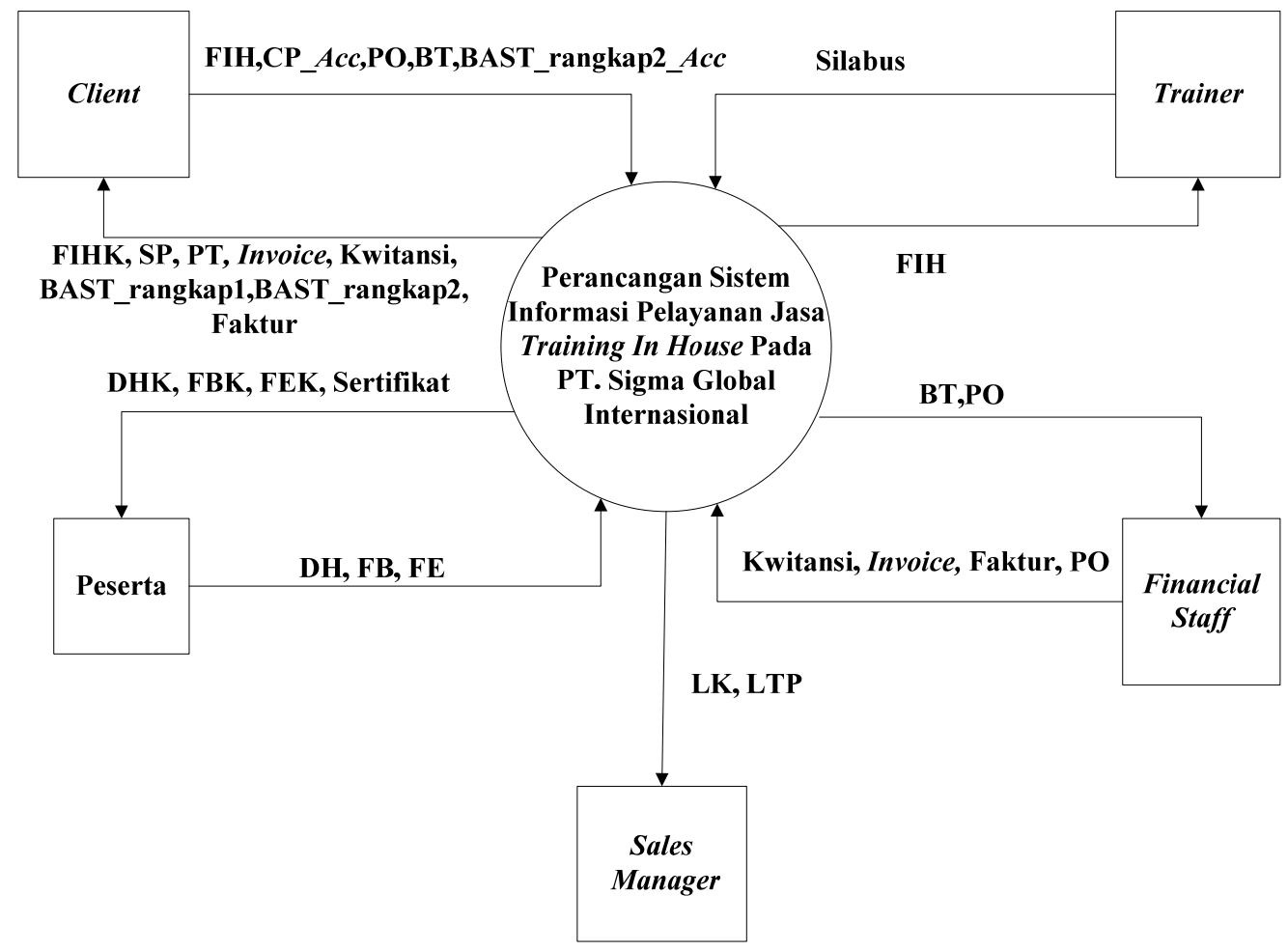

Gambar 1 Diagram konteks.

FIH

FIHK

CP_Acc

$\mathrm{PO}$

SP

PT

BAST
: Form In-house Training

: Form In-house Training Kosong

: Fotocopy Proposal Acc

: Purchase Order

: Surat Penawaran

: Proposal Training

: Berita Acara Serah Terima
DHK : Daftar Hadir Kosong

DH : Daftar Hadir

BT : Bukti Transfer

FB : Form Biodata

FE : Form Evaluasi

FEK : Form Evaluasi Kosong

FBK : Form Biodata Kosong 


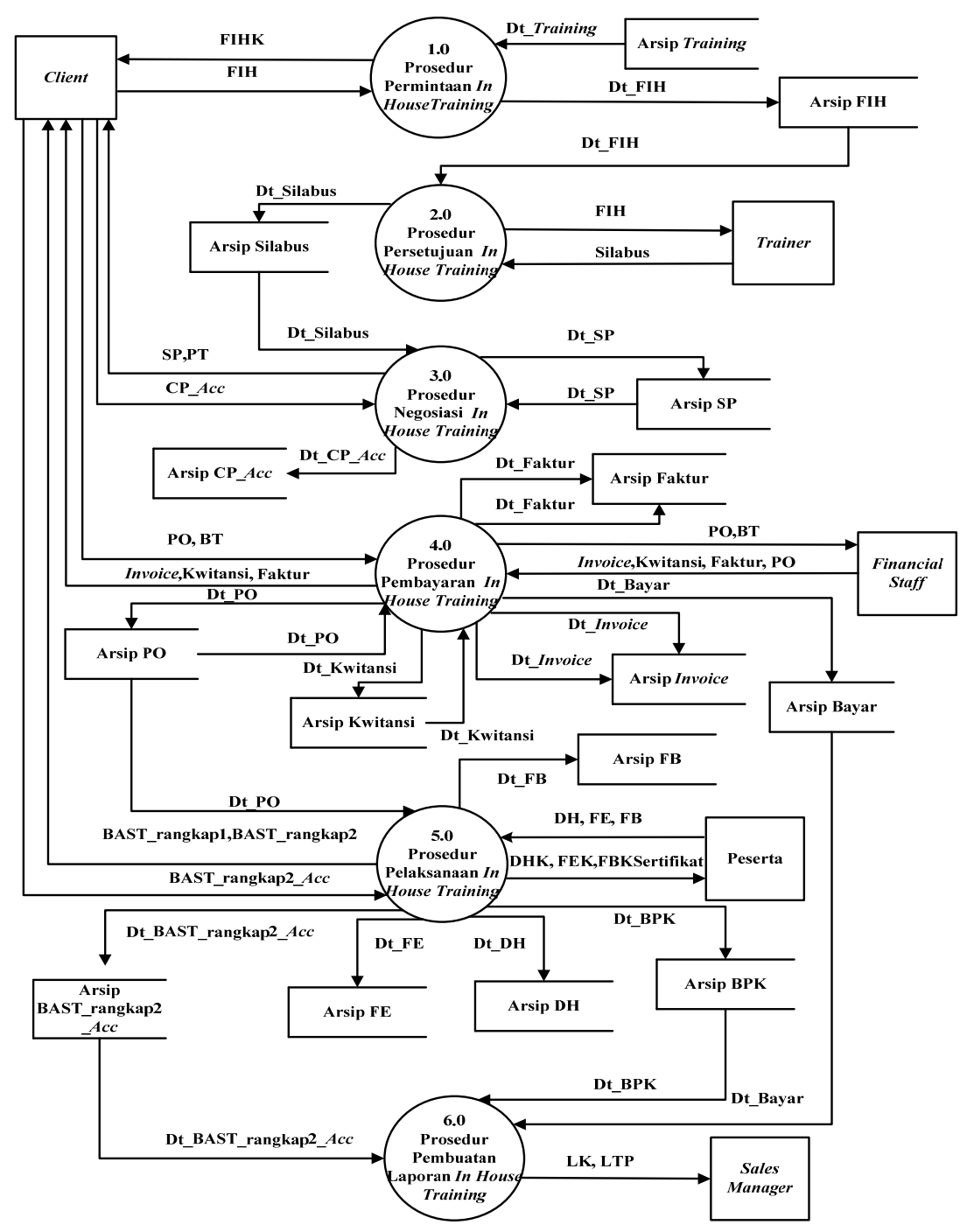

Gambar 2 Diagram Nol.

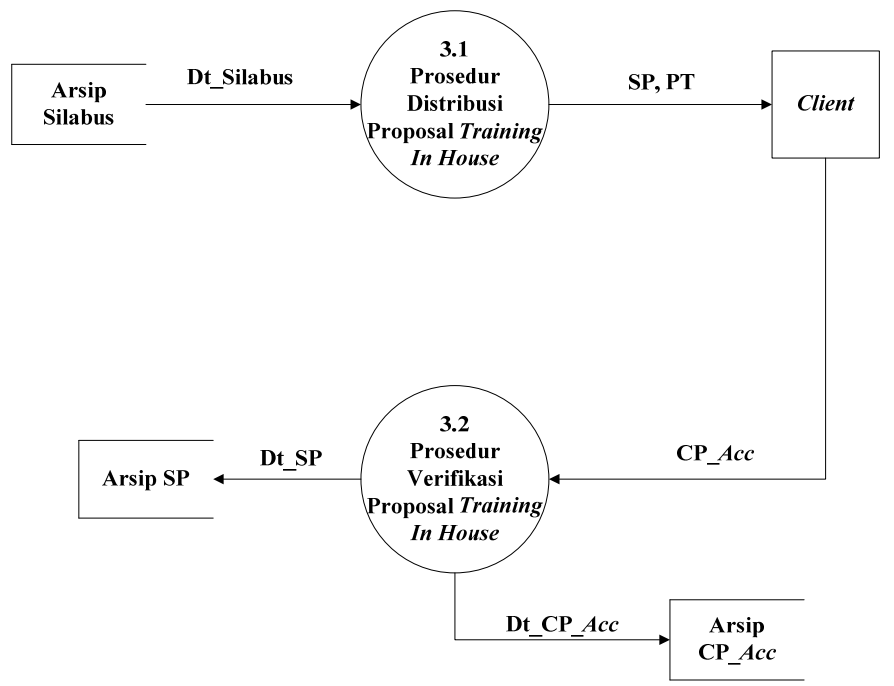

Gambar 3 Diagram Detail Proses 3.0. 


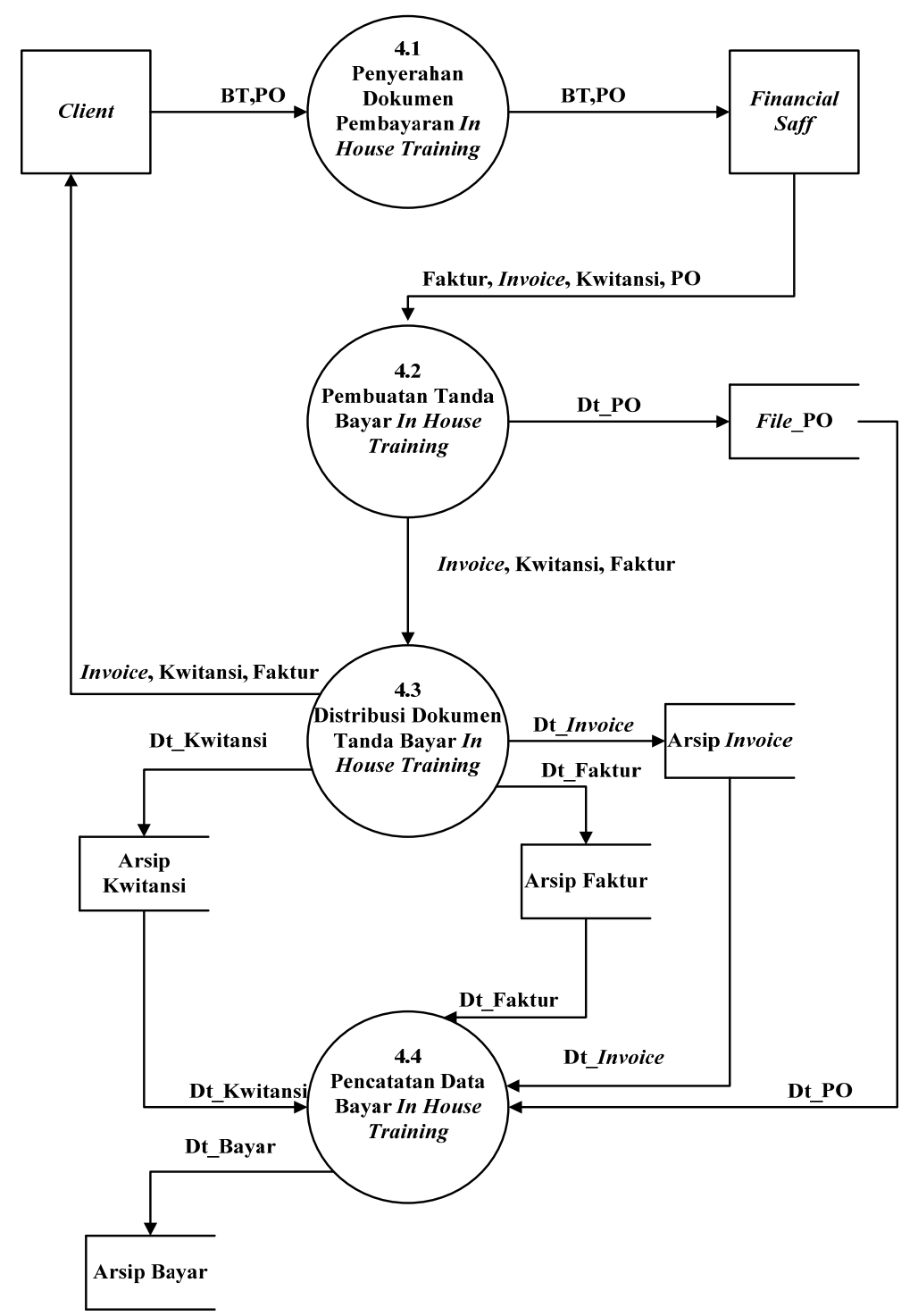

Gambar 4 Diagram Detail Proses 4.0. 